\title{
Information Needs of Breast Cancer Patients at Cancer Diseases Hospital, Lusaka, Zambia
}

\author{
Beauty Lilala Namushi', Marjorie Kabinga Makukula², Patricia Katowa Mukwato² \\ ${ }^{1}$ Cancer Diseases Hospital, Lusaka, Zambia \\ ${ }^{2}$ School of Nursing Sciences, University of Zambia, Lusaka, Zambia \\ Email: beautynamushi@yahoo.co.uk
}

How to cite this paper: Namushi, B.L. Makukula, M.K. and Mukwato, P.K. (2020) Information Needs of Breast Cancer Patients at Cancer Diseases Hospital, Lusaka, Zambia. Advances in Breast Cancer Research, 9, 34-53. https://doi.org/10.4236/abcr.2020.92004

Received: February 28, 2020

Accepted: April 23, 2020

Published: April 26, 2020

Copyright (c) 2020 by author(s) and Scientific Research Publishing Inc. This work is licensed under the Creative Commons Attribution International License (CC BY 4.0).

http://creativecommons.org/licenses/by/4.0/

(c) (i) Open Access

\begin{abstract}
Background: Breast cancer is the second most common cancer worldwide and the second most common among Zambian women. Breast cancer diagnosis being a stressful experience, causes psychological and emotional disruption that can be abated by meeting information needs of the affected patients. In light of the escalating cases of Breast cancer among the Zambian women, the study examined a special aspect of cancer management which is usually neglected in most cases. Aim: The main objective of the study was to assess information needs of breast cancer patients at the Cancer Diseases Hospital in Lusaka, Zambia using a modified structured interview schedule adopted from the Toronto Information Needs Questionnaire-Breast Cancer (TINQ-BC). Methods: A descriptive cross-sectional design was used to elicit the information needs of breast cancer patients. One hundred and ten ( $97 \%$ response rate) participants were selected using simple random sampling method and data was collected using a modified structured interview schedule adopted from the Toronto Information Needs Questionnaire-Breast Cancer (TINQ-BC). Stata 10.0 (StataCorp, 2008) was employed for all quantitative data analysis and graphical presentation of data. Results: The overall score for information needs was obtained by adding the scores across all the five information needs categories which were further divided into three categories namely: low important scores, of less than $50 \%$, moderately important scores of 50\% - 70\% and highly important scores ranged above $70 \%$ of the 200 total scores. Out of the 110 participants recruited, $88(80 \%)$ indicated that the information across the five categories was moderately important. Logistic regression of information needs and posited determinants revealed that anxiety levels; education level; presence of co-morbidity; and being on treatment were significant determinants of patients' informational needs (Effect's $\mathrm{p} \leq 0.05$ ). Conclusion: The findings of this study support the idea that breast cancer patients are seeking more information on their illness, hence information provision is one of the most
\end{abstract}


important factors for providing high quality cancer care across the whole cancer continuum. Therefore, appreciating the information needs of breast cancer patients is substantial in improving care.

\section{Keywords}

Information Needs, Breast Cancer, Breast Cancer Patients

\section{Introduction}

According to world statistics, cancer is a leading cause of disease worldwide with an estimated 14.1 million new cases for the year 2012 and 8.2 million deaths [1]. In females breast cancer is the most common cancer diagnosed accounting for $23 \%$ of the total cancer cases and $14 \%$ of mortality from cancer [2]. In Zambia, breast cancer is the second common cancer among women after cervical cancer representing $8 \%$ of total cancer cases seen at the Cancer Diseases Hospital (CDH) with an age adjusted rate of 45 years [3]. The diagnosis of cancer is a major lifethreatening condition regardless of the stage at which it is made. Those diagnosed encounter stress, anxiety, fear of death and sense of loss of hope, [4] [5] of which breast cancer is not an exceptional as it also creates emotional distress for patients as well as family members [6] [7] [8]. Studies have shown that with the advancement in Breast cancer treatments, patients can go through them without experiencing major bodily distortion than before. However, the disease itself and more complex and prolonged treatments over a period of time cause patients to experience treatment-related distress, fear of recurrence, altered body image and sexuality, as well as physical toxicities that result from adjuvant therapy which alter the quality of life [6] [7].

Since breast cancer and the consequent treatment is highly traumatizing, the ability of patients to cope with the disease may be dependent on meeting their information needs. Studies have indicated that perceiving information needs and meeting them, help patients be well informed, leading to better health outcomes [9] [10]. The value of meeting the information needs of patients with life limiting conditions such as Breast cancer is very critical because a patient's misunderstanding of a condition and its care can result in non-compliance to a doctor's recommendations, significantly and adversely affecting outcomes. Adequately informed patients are able to manage their disease and are more involved with their treatment choices and health care. Research published in Korea by Yi et al., [10] showed that patients with Breast Cancer benefit in terms of knowledge acquisition. The study found that "patients with cancer who had been adequately informed about their illness and treatment were better able to reduce their feelings of distress, cope with the uncertainty of the illness, and be more satisfied with the care" [10]. In addition, breast cancer treatments can be extremely intimidating, therefore adequate knowledge about what can be expected during and after 
treatment is important. Provision of information can help these patients in terms of physiological as well as psychological outcomes, enabling them to regain control over their lives and participate fully with treatment.

In view of the importance of information exchange and treatment decisionmaking in cancer care, studies have reported valuable findings regarding the advantages of meeting information needs of Breast Cancer patients. These include patients' improved adherence to therapy, increased abilities to cope with the illness and more appropriate use of health service resources [9] [11]. In order to achieve these meaningful health outcomes Breast Cancer patients' participation in the care is very important and this can only be done if these patients have sufficient information to help them make decisions. Although information satisfaction is a major predictor of quality of life, the patients' ultimate health outcome is greatly influenced by the way they deal with the information received during their illness. With several studies documenting the benefits of providing adequate information (Yi et al., 2007; Eheman, 2009; Li, 2011; Lei et al., 2011) [10] [12] [13] [14], unmet information needs are associated with negative health-related quality of life (Ladd, 2016) [15]; such as high levels of anxiety and depression (Halkett et al., 2012) [16]; negative illness perceptions, unrealistic expectations, sometimes costly legal actions and failure for patients to give an informed consent (PIF, 2012) [17]. In order to mitigate these negative effects Breast Cancer patients' information needs should be met as information provision is one of the most important elements of care across the whole cancer continuum. Therefore, in view of the importance of information exchange and treatment decision-making in cancer care, the study assessed information needs in an effort to assist the clinicians in understanding and addressing the information needs of breast cancer patients.

\section{Materials and Methods}

\subsection{Study Design, Setting and Participants}

A descriptive, non-intervention, cross sectional design was used to investigate the information needs of patients with breast cancer. The study was conducted at Cancer Diseases Hospital (CDH), a government hospital serving patients from across the country and neighboring countries. Being the only Cancer Diseases Hospital in the country, it offers specialist in-patient and out-patient services and serves as a referral hospital for all confirmed cancer cases in Zambia. The population for the study comprised all breast cancer patients aged 18 years and above who were being treated for cancer or being followed-up at Cancer Diseases Hospital from April 2006 to September 2017. Participants were selected using simple random sampling method and were considered eligible for inclusion if they were aged 18 years and above, living with breast cancer diagnosis, willing to participate in the study and were physically and cognitively able to participate in the interview process. The study excluded new patients who were just being screened on the day of interviews. 


\subsection{Data Collection Procedure}

Ethical clearance was granted from the University of Zambia, Biomedical Research Ethics Committee and interviews were conducted by the researcher over a period of six weeks. Participants were given time to go through the information sheet and afterwards were availed with the consent form on which they appended their signatures as endorsement to participate in the study. The researcher then administered the questionnaire in face to face interviews which took approximately 20 minutes.

\subsection{Instruments}

The Modified structured interview schedule adopted from Toronto Information Needs Questionnaire-Breast Cancer (TINQ-BC) by Galloway et al. [18] was used to evaluate the information needs of breast cancer patients. The tool was developed to assess the specific information needs of women with breast cancer and comprised of five subscales which included disease, investigative tests, treatment options, physical, and psychosocial needs. Participants were asked to rate the importance of each item on a Likert-type scale with one = "not important", two, = "slightly important", three = "moderately important", four = "very important", and five = "extremely important". The overall score for information needs was obtained by adding the scores across all the 5 information needs categories. Therefore, for each patient the information needs score was between minimum 40 units and maximum 200 units. Further, the scores on the information needs were divided into three categories; low important scores were less than $50 \%$ of 200, moderately important was from 50\% - 70\% and highly important scores ranged above $70 \%$. The Hamilton Anxiety Rating Scale (HAM-A) was also adopted from occupational medicine and used in measuring the patient's anxiety [19]. It is a widely used and well-validated tool for measuring the severity of a patient's anxiety. The scale consists of 14 items, each defined by a series of symptoms and measures both psychic anxiety (mental agitation and psychological distress) and somatic anxiety (physical complaints related to anxiety) with the sensitivity of $85.7 \%$ and specificity of $63.5 \%$.

\subsection{Data Analysis}

Stata 10.0 (StataCorp, 2008) was employed for all quantitative data analysis and graphical presentation of data. Association between breast cancer patients' information needs and eight independent variables including demographic and disease characteristics namely, Level of Anxiety, Marital Status, Age Group, Education, Cancer Stage, Length of Illness, Presence of Co-morbidities, and Occupation were investigated.

The crude strength of association between having information needs and posited predictors information needs was estimated with Pearson's chi-squared test. All the variables determined to be having a statistically significant association with the primary outcome (significant level of $\mathrm{p}<0.05$ on the $\mathrm{Chi}^{2}$ Statistic) were em- 
ployed to conduct multivariate analysis in a logistic regression model. These variables also present as a priori determinants in future research. However, variables that not indicating a crude association with the information needs (i.e. $\mathrm{p}>0.05$ ) were all included in the final logistic regression multivariate model to be examined as possible confounders of information needs.

\section{Results}

Interviews were conducted with 110 patients, more than $50 \%$ of participants 63 (57.3\%) were aged above 50 years, 56 (50.9\%) were married and 92 (83.6\%) reported to have been living with breast cancer for at least $1-4$ years. Sociodemographic data are presented in Table 1.

Table 1. Socio-demographic characteristics of the participants (n-110).

\begin{tabular}{|c|c|c|}
\hline Variable & Frequency & Percentage (\%) \\
\hline \multicolumn{3}{|l|}{ Age (years) } \\
\hline$<40$ & 16 & 14.5 \\
\hline $40-50$ & 31 & 28.1 \\
\hline$>50$ & 63 & 57.2 \\
\hline \multicolumn{3}{|l|}{ Marital status } \\
\hline Married & 56 & 50.9 \\
\hline Single/Divorced/Widowed & 54 & 49.1 \\
\hline \multicolumn{3}{|l|}{ Occupation } \\
\hline Formal employment & 20 & 18.2 \\
\hline Informal/self-employment & 40 & 36.4 \\
\hline Unemployed & 50 & 45.5 \\
\hline \multicolumn{3}{|l|}{ Education Level } \\
\hline No education & 13 & 11.8 \\
\hline Primary & 31 & 28.2 \\
\hline Secondary & 32 & 29.1 \\
\hline Tertiary & 34 & 30.9 \\
\hline \multicolumn{3}{|l|}{ Duration with Breast Cancer } \\
\hline $1-4$ years & 92 & 83.6 \\
\hline 5 - 9 Years & 14 & 12.7 \\
\hline$>10$ years & 4 & 3.6 \\
\hline \multicolumn{3}{|l|}{ Tumor stage at diagnosis } \\
\hline 0 & 1 & 0.9 \\
\hline I & 11 & 10.0 \\
\hline II & 25 & 22.7 \\
\hline III & 18 & 16.4 \\
\hline IV & 15 & 13.6 \\
\hline Unknown & 40 & 36.4 \\
\hline \multicolumn{3}{|l|}{ On Cancer treatment } \\
\hline Yes & 93 & 84.6 \\
\hline No & 17 & 15.4 \\
\hline \multicolumn{3}{|l|}{ Co-Morbidity } \\
\hline No Co-morbidity & 68 & 61.8 \\
\hline Co-morbidity present & 42 & 38.5 \\
\hline
\end{tabular}




\subsection{Information Needs}

In order to assess the information needs of the participants, Item analysis determined that 41 items in five subscales should be retained in the questionnaire. The subscales were categorized as information needs on Disease, Investigative Tests, Treatments, Physical, and Psychosocial needs. The Likert scale was used to elicit information from the participants. The Likert scale scored information needs items from 1 to 5 with 5 indicating the highest level of need. In order to come up with the overall picture of how important the participants thought the information was, the overall score for information needs was obtained by adding all the scores across all the 5 information needs categories (Table 2). Therefore, for each patient the information needs score was between minimum 40 units and maximum 200 units. Further, the scores on the information needs were divided into three categories; low important scores were less than 50\%, moderately important was from $50 \%-70 \%$ and highly important scores ranged above $70 \%$ of 200 total scores. Among the participants majority $80 \%$ of the respondents thought that the information from all the categories was moderately important while $10.9 \%$ participants thought it was highly important and only $9.1 \%$ stated that the information was of low importance. The domains that were given most importance covered questions about investigations (76.4\%) and treatment (73.6\%) with psychosocial (70\%) aspects rated the least important.

Figure 1 illustrates the opinion of the participants on all the scores of the combined subscales of information needs. Out of the 110 participants recruited, $80 \%$ of them indicated that the information was moderately important, $10.9 \%$ participants thought it was highly important and $9.1 \%$ had the opinion that the information was of low importance.

\subsection{Crude Association between Information Needs and Posited Needs Determinants}

The crude strength of association between having information needs and posited predictors of information needs were estimated with Pearson's chi-squared test. All the variables determined to be having a statistically significant association with the primary outcome (significant level of $\mathrm{p}<0.05$ on the $\mathrm{Chi}^{2}$ Statistic) were included see Table 3. From Table 4 below, only Anxiety level was associated with information needs on bivariate analysis. We therefore included all the posited determinants in the multivariate logistic regression model because they are possible confounding variables meaning that the true effect of these variables could be masked by the confounding effects of the other variables. Therefore, in order to obtain the true effects of these variables we conducted a multivariate analysis with logistic regression and controlled for the confounding effects. The final results in the multilevel model show that indeed we had confounding effects as some of the variables that showed no association on crude chi square analysis were significantly affecting the information needs after logistic regression multivariate analysis Table 3. 
Table 5 shows most respondents (81\%) cited health providers' lack of ample time to attend to them as a common barrier to accessing information. $75.9 \%$ of the respondents alluded to health care providers as being too busy to give them information. $72.9 \%$ thought there were too many patients and $50 \%$ of the respondents thought patients were scared to ask questions.

Table 2. Total overall scores of information needs categories.

\begin{tabular}{|c|c|c|c|c|c|}
\hline $\begin{array}{c}\text { Information } \\
\text { Needs Categories }\end{array}$ & $\begin{array}{c}\text { Number of } \\
\text { information } \\
\text { need questions }\end{array}$ & $\begin{array}{c}\text { Minimum } \\
\text { possible } \\
\text { Rating }\end{array}$ & $\begin{array}{c}\text { Maximum } \\
\text { possible Rating } \\
\text { per question }\end{array}$ & $\begin{array}{c}\text { Minimum } \\
\text { score per } \\
\text { patient }\end{array}$ & $\begin{array}{c}\text { Maximum } \\
\text { score per } \\
\text { patient }\end{array}$ \\
\hline Disease Process & 7 & 1 & 5 & 7 & 35 \\
\hline $\begin{array}{l}\text { Investigative } \\
\text { tests done }\end{array}$ & 5 & 1 & 5 & 5 & 25 \\
\hline $\begin{array}{l}\text { Treatment } \\
\text { Modalities }\end{array}$ & 15 & 1 & 5 & 15 & 75 \\
\hline Physical Needs & 10 & 1 & 5 & 10 & 50 \\
\hline $\begin{array}{c}\text { Psychosocial } \\
\text { Needs }\end{array}$ & 3 & 1 & 5 & 3 & 15 \\
\hline $\begin{array}{l}\text { Total Possible } \\
\text { Overall Score }\end{array}$ & & & & 40 & 200 \\
\hline
\end{tabular}

Table 3. Association between the information needs of breast cancer patients and the posited determinants (n-110).

\begin{tabular}{|c|c|c|c|c|}
\hline \multicolumn{2}{|c|}{ Factors influencing information needs } & \multirow[t]{2}{*}{ Odds Ratio } & \multirow[t]{2}{*}{$\mathrm{p}$ value } & \multirow[t]{2}{*}{$\begin{array}{c}95 \% \text { confidence } \\
\text { interval }\end{array}$} \\
\hline \multirow{3}{*}{ Anxiety } & $\begin{array}{l}\text { Anxiety (Ref: Mild } \\
\text { Anxiety) }\end{array}$ & & & \\
\hline & Moderate Anxiety & 0.5 & 0.550 & 0.06 \\
\hline & High Anxiety & 11.7 & 0.028 & 1.30 \\
\hline \multirow{5}{*}{ Education } & $\begin{array}{l}\text { Education (Ref: No } \\
\text { formal Education) }\end{array}$ & & & \\
\hline & Primary & 2.6 & 0.545 & 0.12 \\
\hline & Secondary & 7.8 & 0.176 & 0.40 \\
\hline & College & 11.0 & 0.120 & 0.53 \\
\hline & University & 45.8 & 0.027 & 1.55 \\
\hline \multirow{2}{*}{$\begin{array}{c}\text { Presence of } \\
\text { Co-morbidity }\end{array}$} & No & 1.5 & 0.615 & 0.33 \\
\hline & Yes & 39.0 & 0.028 & 1.49 \\
\hline On Treatment & Yes & 0.01 & 0.004 & 0.09 \\
\hline
\end{tabular}

Logistic Regression, from the measures of effect (Odds Ratio, $\mathrm{p}$ values) and confidence intervals, determined that anxiety levels $(\mathrm{OR}=11.7$; $\mathrm{p}$ value 0.028$)$; education level $(\mathrm{OR}=45.8$; $\mathrm{p}$ value 0.027 , for University level); presence of co-morbidity $(\mathrm{OR}=39$; $\mathrm{p}$ value 0.028$)$; and being on treatment $((\mathrm{OR}=0.01$; $\mathrm{p}$ value $0.004)$ ) were significant determinants of patients' informational needs (Effect's $\mathrm{p} \leq 0.05$ ). 
Proportion of Breast Cancer Patients (\%)

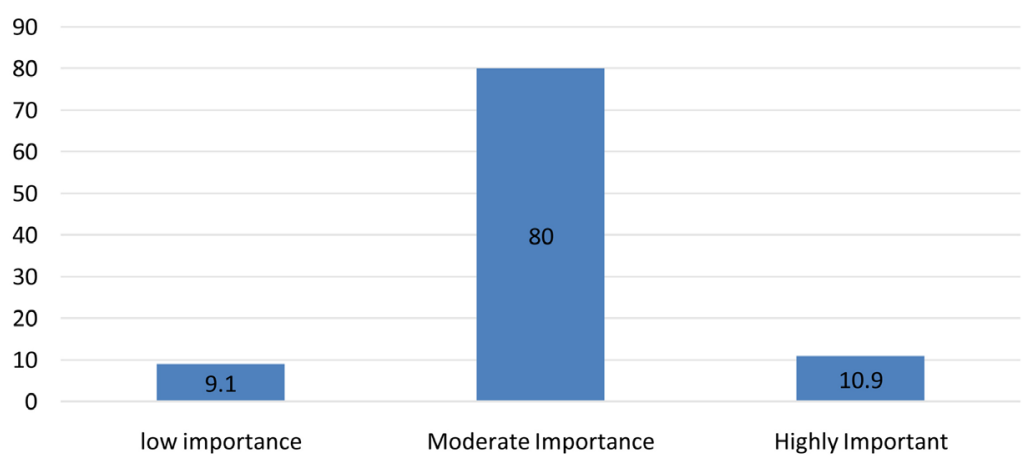

Figure 1. Overall information needs of breast cancer patients (n-110).

Table 4. Strength of association between having information needs and posited predictors of information needs determinants among breast cancer patients.

\begin{tabular}{ccc}
\hline \multirow{2}{*}{$\begin{array}{c}\text { Posited predictors of } \\
\text { information needs }\end{array}$} & \multicolumn{2}{c}{ Strength of Association with information needs } \\
\cline { 2 - 3 } & Pearson chi $^{2}$ statistic & p value \\
\hline Anxiety Level & 8.0 & 0.018 \\
Age group & 7.5 & 0.271 \\
Education Level & 8.8 & 0.066 \\
Presence of co-morbidities & 3.3 & 0.346 \\
On treatment & 3.5 & 0.063 \\
Cancer Stage & 6.3 & 0.281 \\
Length of illness & 2.2 & 0.331 \\
\hline
\end{tabular}

Table 5. Barriers to accessing information by breast cancer patients.

\begin{tabular}{ccc}
\hline Barriers faced & Frequency $(\mathrm{n})$ & Percentage (\%) \\
\hline Health providers "lack of ample time to attend to patients" & 60 & $81 \%$ \\
Health care givers are too busy & 56 & $75.6 \%$ \\
Too many patients & 54 & $72.9 \%$ \\
Understaffing of hospitals & 33 & $44.5 \%$ \\
Fear in patients to question doctors & 37 & $50 \%$ \\
Professionals scared of patients' reactions & 20 & $27.2 \%$ \\
\hline
\end{tabular}

\section{Discussion}

The first objective was to assess the information that breast cancer patients desired to know about their disease. The findings of this study revealed that the majority $80 \%$ of the participants showed significant information needs on all the categories of information. The participants were interested in receiving moderate information in all the categories of information needs. This could have been attributed to the questions asked in the adapted TINQ-BC questionnaire were participants may be comfortable rating themselves neither low no high. This is supported by McLeod [20] who stated that sometimes the "validity of Likert Scale 
attitude measurement can be compromised due social desirability" meaning that "individuals may lie to put themselves in a positive light". This finding could also be attributed to the fact that patients want to retain hope and therefore only want to receive positive information. In a study conducted in London by Leydon et al. [21], it was suggested that patients may not be interested in information beyond what their physicians could offer in order to maintain hope. In addition, Holmes [6] noted that women placed a high importance on information that is tailored to meet their specific need in managing their illness.

\subsection{Information Needs}

In this study information on Investigative tests were positioned as first in priority of information needs. This could be attributed to that investigative tests in cancer management are done so often in order to monitor patients' treatment. The results correspond with the study findings of Holmes [6] which revealed that women desire information regarding the rationale for the test as blood work often signifies how their body is adapting to treatment. This study found information regarding treatment as the second priority. The reason could be that these patients want to know what is involved with treatment, including the benefits and risks, any options, and what may happen if the patient chooses not to go ahead with treatment. The findings are similar to the outcome by Holmes [6] who found that treatment information is necessary to help women cope with and understand what is ahead in their cancer trajectory. Information regarding the disease process provides women with the information needed to make informed decisions regarding their treatments.

Findings of this study revealed information regarding the disease and physical needs as third in priority. This could be due to that, the disease items were assessing information needs about the nature and process of the disease, while physical items assessed information needs about the preventive, restorative and maintenance care that may be needed as a result of the disease and treatments. Hence Breast Cancer patients in this study were already aware of their diagnosis and could have started coming to terms with what they were going through therefore making both the disease and physical needs third in priority. This was contrary to what Teriman et al., [22] found in their study where the information on the disease was second in priority. The study suggested that it was natural for patients to want to know what type of cancer and what stage of the disease they have, as most patients fear certain types of cancer and advanced stage of the disease since they are usually associated with shorter survival.

\subsection{Factors Influencing Information Needs}

From the Chi-squared association only anxiety ( $\mathrm{p}$ value 0.018 ) was significantly associated with information needs statistically. Therefore, in order to obtain the true effects of these variables we conducted a multivariate analysis with logistic regression and controlled for the confounding effects. In this study, anxiety, at- 
taining university education, presence of co-morbidities and being on treatment were significantly associated with information needs.

In our study patients with high anxiety were 12 times more likely to have information needs $(\mathrm{OR}=11.7$; $\mathrm{p}$ value 0.028$)$. This finding shows that a diagnosis of breast cancer causes a state of anxiety as breast cancer is a life-threatening disease. The findings of this study agree with You's [23] findings which revealed that approximately $30 \%$ to $54 \%$ of patients suffer from anxiety within two years after diagnosis and $13 \%$ to $15 \%$ have symptoms of anxiety that persist for years. When a client experiences anxiety the need for information increases and consequently health care providers should provide the necessary information. This study suggests that anxiety is common in cancer patient populations, and it's essential for health care professionals to recognize and manage it. Therefore, findings of this study suggest that increased information supply to cancer patients can be used as a management strategy by cancer care professionals, hence the result of this study collaborates with results by Faller et al., [24] who found that there was a relationship between information satisfaction and symptoms of depression and anxiety. Hence, stating that "provision of information may reduce subsequent depression and anxiety, while reducing depression and anxiety levels may increase satisfaction with received information".

In this study, attaining university education was found to affect the information needs of the participants (OR 45.8, p value 0.027). This finding suggests that educated patients have more information needs than those who are not. This could be attributed to that the educated are able to communicate with health professionals freely and may ask questions where they are not clear. The other reason could be that the educated patients seek medical attention early and are usually involved in their care and would want to understand whatever the health professionals are doing on them. The results are similar to a study conducted by Eheman [12], which indicated that higher education attainment influence information needs and coping skills of patients. These findings therefore have an implication for how health professionals interact with well- and less-educated patients.

The findings in this study revealed that the presence of other diseases such as hypertension and diabetes were associated with information needs $(O R=39 ; \mathrm{p}$ value 0.028 ). This could be that breast cancer is already a distressing disease, having two conditions makes the patient stressful hence having a lot of questions on how they will cope. The results are similar to a study conducted by Baine et al., [25] which showed that the psychological stress caused by other diseases were the motivating factor for seeking more information. Furthermore, patients with comorbidity have poorer survival; poorer quality of life, and higher health care costs which are the most important determinant of information seeking.

In this study patients who were not on treatment compared to patients on treatment were $99 \%$ times less to seek for information ( $O R=0.01$; p value 0.004 ). This could be due to that patients on treatment were experiencing fear of whether 
they will recover or not, and probably could have been facing side effects of treatment. In addition, studies by Ladd [15] and Greco et al., [26] reported patients searching for medical information which included facts on chemotherapy, radiotherapy, and surgery. Therefore, the study suggests that special attention should be paid to the breast cancer patients as information and social support may help improve their prognosis.

\subsection{Barriers to Accessing Information}

Respondents were asked to state the problems they encountered when looking for information. The study revealed that respondents indicated that the health providers did not have adequate time to attend to patients as a common barrier to accessing information. Respondents noted that there were few doctors to attend to too many patients; hence they were mindful of the time to talk and ask questions. Thus, most respondents cited limited interaction time with doctors due to high patient volume as a barrier to accessing information, as doctors were too busy. The findings are similar to those conducted by Eames et al., [27] in the United States of America who noted similar results which included not knowing what to ask, patients being "pushy" to get information, and busy or inadequate numbers of health professionals.

\subsection{Limitations of the Study}

The study was a cross-sectional study; therefore, it couldn't measure the information needs of patients in different stages of the disease trajectory and further longitudinal studies will be needed in this area. The other limitation was the adopted TINQ-BC collection tool which could compromise the quality of data because the respondents may only give the answers, they thought were socially acceptable. Another limitation is that respondents were not asked about satisfaction with information received from medical professionals therefore it was difficult to elicit if their needs were met or not so as to know which information they needed.

\section{Conclusion}

The diagnosis of breast cancer is a stressful experience; therefore, information provision is one of the most important factors for providing high quality cancer care across the whole cancer continuum. Appreciating the information needs of breast cancer patients is substantial in improving care.

\section{Acknowledgements}

My supervisor, Dr. M. Makukula for her guidance and support, without which, I would have not succeeded with this study.

I acknowledge the Norwegian Agency for Development (NORAD) through the NORHED QZA-0848 QZA-MW-13/00032 Grant, for the financial support. 


\section{Conflicts of Interest}

The authors declare no conflicts of interest regarding the publication of this paper.

\section{References}

[1] Ferlay, J., Soerjomataram, I., Ervik, M., Dikshit, R., Eser, S., Mathers, C., et al. (2013) GLOBOCAN 2012 v1.0, Cancer Incidence and Mortality Worldwide: IARC Cancer Base No. 11. International Agency for Research on Cancer, Lyon, France.

[2] Jemal, A., Bray, F., Forman. D., O’Brien, M., Ferlay, J., Center, M., et al. (2012) Cancer Burden in Africa and Opportunities for Prevention. Cancer, 118, 4372-4384. https://doi.org/10.1002/cncr.27410

[3] Cancer Diseases Hospital (2016) Annual Report, Lusaka.

[4] Al-Amri, A. (2010) Saudi towards Disclosure of Cancer Information. Middle East Journal of Cancer, 1, 175-180.

[5] Katowa, M.P., Mwape, L., Maimbolwa, C.M., Muleya, C.M. and Namushi, L.B. (2015) Stress and Coping with Cervical Cancer by Patients: A Qualitative Inquiry. International Journal of Psychology and Counseling, 7, 94-105. https://doi.org/10.5897/IJPC2015.0313

[6] Holmes, D.M. (2008) Breast Cancer Patients' Expressed Information Needs: Results of a Literature Review. University of Victoria, Victoria. https://dspace.library.uvic.ca/handle/1828/4276

[7] Ganz, P.A. (2008) Psychological and Social Aspects of Breast Cancer. Oncology Continuing Medical Education Journal, 22, 642-650.

[8] Ankem, K. (2015) Assessing Cancer Patients' Health Information Needs: A Standardized Approach. iRinformation Research, 20, No. 2.

[9] Husson, O., Mols, F. and van de Poll-Franse, L.V. (2011) The Relation between Information Provision and Health Related Quality of Life, Anxiety and Depression among Cancer Survivors: A Systematic Review. Annals of Oncology, 22, 761-762. https://doi.org/10.1093/annonc/mdq413

[10] Yi, M., Cho, J., Dong-Young, N., Mi-Ryung, S., Jung-Lim, L. and Hee-Soon, J. (2007) Informational Needs of Korean Women with Breast Cancer: Cross-Cultural Adaptation of the Toronto Informational Needs Questionnaire of Breast Cancer. Asian Nursing Research, 1, 176-186. https://doi.org/10.1016/S1976-1317(08)60020-1

[11] Yusuf, T.I. (2012) Information Needs Sources and Information Seeking Behaviour of Women Artisans in Offa Metropolis. Library Philosophy and Practice, 10, 2012.

[12] Eheman, C., Berkowitz, Z., Lee, J.W., Mohile, S.G., Purnell, J.Q., Roscoe, J.A., et al. (2009) Information-Seeking Styles among Cancer Patients before and after Treatment by Demographics and Use of Information Sources. Journal of Health Communication, 14, 487-502. https://doi.org/10.1080/10810730903032945

[13] Li, P.W., So, W.K., Fong, D.Y., Lui, L.Y., Lo, J.C. and Lau, S.F. (2011) The Information Needs of Breast Cancer Patients in Hong Kong and Their Levels of Satisfaction with the Provision of Information. Cancer Nursing, 34, 49-57. https://doi.org/10.1097/NCC.0b013e3181ef77a0

[14] Lei, C.P., Har, Y.C. and Abdullah, K.L. (2011) Informational Needs of Breast Cancer Patients on Chemotherapy: Differences between Patients' and Nurses' Perceptions. Asian Pacific Journal of Cancer Prevention, 12, 797-802. 
[15] Ladd, L.D. (2016) Information Needs and Information Sources of Patients Diagnosed with Rare Cancer. Virginia Commonwealth University VCU Scholars Compass. https://scholarscompass.vcu.edu/cgi/viewcontent.cgi

[16] Halkett, G., Lobb, A.E., Kristjanson, L. and Spry, N. (2012) Information Needs and Preferences of Women as They Proceed through Radiotherapy for Breast Cancer. Patient Education and Counselling, 86, 396-404. https://doi.org/10.1016/j.pec.2011.05.010

[17] Patient Information Forum Website (2012) Faculty of Pharmaceutical Medicine Annual Symposium: Life or Livelihood: Does Adherence to Medicines Matter? https://www.pifonline.org.uk/faculty-of-pharmaceuticalmedicine-annual-symposiu m-life-or-livelihood-doesadherence-to-medicines-matter

[18] Galloway, S., Graydon, J.D.H., Evans-Boyden, B., et al. (1997) Informational Needs of Women with a Recent Diagnosis of Breast Cancer: Development and Initial Testing of a Tool. Journal of Advanced Nursing, 25, 1175-1183. https://doi.org/10.1046/j.1365-2648.1997.19970251175.x

[19] Thompson, E. (2015) Hamilton Rating Scale for Anxiety (HAM: A Questionnaire Review). Occupational Medicine, 65, 601. https://doi.org/10.1093/occmed/kqv054

[20] McLeod, S. (2008) Attitude Measurement. Likert Scale, Likert Scale. https://www.simplypsychology.org/likert-scale.html

[21] Leydon, M.G., Boulton, M., Moynihan, C., Jones, A., Mossman, J., Boudioni, M., et al. (2000) Cancer Patients' Information Needs and Information Seeking Behaviour: In Depth Interview Study. British Medical Journal, 320, 909-913.

https://doi.org/10.1136/bmj.320.7239.909

[22] Tariman, J.D., Doorenbos, A., Karen, G., Schepp, K.G., Singhal, S. and Berry, D.L. (2014) Information Needs Priorities in Patients Diagnosed with Cancer: A Systematic Review. Journal of the Advanced Practitioner in Oncology, 5, 115-122. https://doi.org/10.6004/jadpro.2014.5.2.10

[23] You, J., Lu, Q., Zvolensky, J.M., Meng, Z., Kay Garcia, G. and Lorenzo Cohen, L. (2017) Anxiety- and Health-Related Quality of Life among Patients with Breast Cancer: Across Cultural Comparison of China and the United States. Journal of Global Oncology, 4, 1-9. https://doi.org/10.1200/JGO.2016.008763

[24] Faller, H., Strahl, A., Richard, M., Niehues, C. and Meng, K. (2016) The Prospective Relationship between Satisfaction with Information and Symptoms of Depression and Anxiety in Breast Cancer: A Structural Equation Modeling Analysis. Psychooncology, 26, 1741-1748. https://doi.org/10.1002/pon.4358

[25] Baine, M., Sahak, F., Lin, C., Chakraborty, S., Lyden, E. and Batra, S.K. (2011) Marital Status and Survival in Pancreatic Cancer Patients: A SEER Based Analysis. PLoS ONE, 6, e21052. https://doi.org/10.1371/journal.pone.0021052

[26] Greco, A., Cappelletti, E.R., Monzani, D., Pancani, L., D’Addario, M., Magrin, M.E., et al. (2016) A Longitudinal Study on the Information Needs and Preferences of $\mathrm{Pa}$ tients after an Acute Coronary Syndrome. BMC Family Practice, 20, 136. https://doi.org/10.1186/s12875-016-0534-8

[27] Eames, S., Hoffmann, T., Worrall, L. and Read, S. (2010) Stroke Patients' and Carers' Perception of Barriers to Accessing Stroke Information. Top Stroke Rehabilitation, 17, 69-78. https://doi.org/10.1310/tsr1702-69 


\section{Appendices}

\section{Appendix I: Information Sheet: English}

Study Title: Information Needs of Breast Cancer Patients at Cancer Diseases Hospital in Lusaka, Zambia.

\section{1) Introduction}

Beauty Lilala Namushi, a student at the University of Zambia in the School of Nursing Science is requesting you to participate in a research whose title is mentioned above. The study to explore breast cancer patients; information needs is important because the findings will help in improving the quality of care for cancer patients. Before you decide whether to participate or not in this study, I would like to explain to you the purpose of the study, the procedure, any risks and discomforts, benefits and what is expected of you. Your participation in this study is entirely voluntary. You are under no obligation to participate; you may choose to participate or not to. If you decline to participate, no privileges will be taken away from you as you seek treatment or support from any organization or individual. If you agree to participate you will be asked to sign this consent form in the presence of a witness. Agreement to participate will not result in any immediate benefits.

\section{2) Purpose of the Study}

A diagnosis of cancer is a fearful experience that has cultural, social and psychological consequences and many patients and their relatives experience physical, psychological, spiritual and family problems (Ankem, 2006; Motlagh et al., 2014). Newly diagnosed patients embark on a journey with uncertain destination, laden with stress and anxiety and desperate for hope and support. Provision of information can help these patients in terms of physiological as well as psychological outcomes enabling them to regain control over their lives and participate fully with treatment. Therefore, this study will obtain information on what breast cancer patients desire to know during the illness trajectory. This information will be identified by analyzing participants' information lived experience. The identified desired information will be used in developing more culturally effective models to deliver information and support to breast cancer patients. Identifying the actual needs of the patients will produce better resource allocation and provide health services more efficiently to meet the needs hence improving the coping mechanism of patients and in turn quality of life.

\section{3) Procedure}

After you have signed the informed consent form and have had a chance to ask questions, you will be requested to answer the questions concerning the information you would desire to know concerning your diagnosis, treatment and prognosis. Then thereafter, you will be asked to make a recommendation on how you want the information delivered to you and how we can improve information delivery to patients.

\section{4) Risks and Discomforts}

No risks are involved in this study; however, you might become emotional 
during the interview as some questions or the process of recalling past experiences may cause discomfort. Should you become emotional and wish not to continue, I will stop and reschedule the interview. With your permission, I will counsel you myself or ask the counsellors who work in the clinic to counsel you.

\section{5) Benefits}

There are no direct benefits to you as a participant, however, the findings will increase our understanding of the desired information that breast cancer patients need. The information provided will help relevant authorities and policy makers to come up with strategies that will be used in developing more culturally effective models to deliver information and support to breast cancer patients.

6) Confidentiality

I will keep information confidential. The people who will know that you are a research participant are members of the research team and all the research materials will be kept in strict confidence. For the purpose of anonymity, you will be identified by a number not by name and personal information will not be released without your written permission.

\section{Appendix II: Consent Form: English}

The purpose of this study has been explained to me and I understand the purpose, benefits, risks and discomforts and confidentiality of the study, I further understand that: If I agree to take part in this study, I can withdraw at any time without having to give an explanation and that taking part in this study is purely voluntary.

$$
\text { I }
$$
(Names)

Agree to take part in answering the questionnaire.

Signed: Date: (Participant)

\section{Interview Schedule}

Semi Structure Interview Schedule for Patients

Title: Information Needs of Breast Cancer Patients at Cancer Diseases

\section{Hospital in Lusaka, Zambia}

Place of interview:

Date of interview:

Time started: Time ended:

Name of interviewer:

Name of interviewee (optional):

Instructions for the interviewer

1) Introduce yourself to the participant.

2) Explain the purpose of the participant.

3) Assure the participant of confidentiality.

4) Obtain an informed consent.

5) If the participant decline to take part, do not force them.

6) Do not write names on the interview schedule.

7) Thank the Participant at the end of each interview. 


\section{Section A: Demographic Data}

1) Age at last birthday
a) Less than 20
b) 20 - 29
c) $30-39$
d) 40 - 49
e) 50 - 59
f) $60-69$
g) 70 and above

2) Marital Status
a) Married
b) Single
c) Divorced
d) Widowed

3) Educational Level
a) No education
b) Primary
c) Secondary
d) College
e) University

4) Occupation
a) Formal employment
b) Informal Employment
c) Unemployed
d) Self employed

5) Religious Denomination

\section{Section B: Medical Related Data}

6) How long have you been living with breast cancer?
a) 1 - 4 years
b) 5 - 9 years
c) 10 and above

7) Tumor Stage at Diagnosis
a) 0
b) I
c) II
d) III
e) IV

8) Current stage

9) Are you on cancer Treatment?
a) Yes
b) No

10) What type of treatment?
a) Chemotherapy
b) Radiotherapy 


\section{c) Chemo radiation}

d) Hormonal

11) Co-morbidities
a) No previous illness
b) Hypertension
c) DM and HTN
d) Renal disease
e) Others

Specify:

\section{Section C: Anxiety Rating Scale}

$0=$ Not present, $1=$ Mild, $2=$ Moderate, $3=$ Severe, $4=$ Very severe .

Anxious mood

(Worries, anticipation of the worst, fearful anticipation, irritability)

Tension

13 (Feelings of tension, fatigability, startle response, moved to tears easily, trembling, feelings of restlessness, inability to relax).

14 Fears

(Of dark, of strangers, of being left alone, of animals, of crowds).

Insomnia

15 (Difficulty in falling asleep, broken sleep, unsatisfying sleep and fatigue on waking, dreams, nightmares, night terrors)

16 Intellectual

(Difficulty in concentration, poor memory)

Depressed mood

17 (Loss of interest, lack of pleasure in hobbies, depression, early waking, diurnal swing).

Somatic (muscular)

18 (Pains and aches, twitching, stiffness, myoclonic jerks, grinding of teeth, unsteady voice, increased muscular tone)

Somatic (sensory)

19 (Tinnitus, blurring of vision, hot and cold flushes, feelings of weakness, pricking sensation).

Cardiovascular symptoms

20 (Tachycardia, palpitations, pain in chest, throbbing of vessels, fainting feelings, missing beat).

Respiratory symptoms

21 (Pressure or constriction in chest, choking feelings, sighing, dyspnea). Gastrointestinal symptoms

22 (Difficulty in swallowing, wind abdominal pain, burning sensations, abdominal fullness, nausea, vomiting, borborygmi, looseness of bowels, loss of weight, constipation).

Genitourinary symptoms

23 (Frequency of micturition, urgency of micturition, amenorrhea, menorrhagia, development of frigidity).

Autonomic symptoms

24 (Dry mouth, flushing, pallor, tendency to sweat, giddiness, tension headache, raising of hair).

Behavior at interview (Fidgeting, restlessness or pacing, tremor of

25 hands, furrowed brow, strained face, sighing or rapid respiration, facial pallor, swallowing) 


\section{Section D: Breast Cancer Information Needs Questionnaire}

Please read each of the following sentences tick in the space that best describes how important it is for you to have this information.

To help me with my illness it is important for me to know.

1) Disease Process

\begin{tabular}{|c|c|c|c|c|c|c|}
\hline & & $\begin{array}{c}\text { Not } \\
\text { Important }\end{array}$ & $\begin{array}{l}\text { Slightly } \\
\text { important }\end{array}$ & $\begin{array}{l}\text { Moderately } \\
\text { Important }\end{array}$ & $\begin{array}{c}\text { Very } \\
\text { Important }\end{array}$ & $\begin{array}{l}\text { Extremely } \\
\text { Important }\end{array}$ \\
\hline 26 & Diagnosis and the stage & & & & & \\
\hline 27 & The cause of breast cancer & & & & & \\
\hline 28 & $\begin{array}{l}\text { How the cancer } \\
\text { behaves in my body }\end{array}$ & & & & & \\
\hline 30 & $\begin{array}{l}\text { Which other organs are } \\
\text { affected or if the cancer is } \\
\text { anywhere else in my body }\end{array}$ & & & & & \\
\hline 31 & $\begin{array}{l}\text { If the breast cancer } \\
\text { will be cured }\end{array}$ & & & & & \\
\hline 32 & $\begin{array}{l}\text { How the illness will affect } \\
\text { my life over the next few } \\
\text { months }\end{array}$ & & & & & \\
\hline 33 & $\begin{array}{l}\text { How my illness will } \\
\text { affect my life in future }\end{array}$ & & & & & \\
\hline
\end{tabular}

\section{2) Investigative tests that are done}

\begin{tabular}{|c|c|c|c|c|c|c|}
\hline & & $\begin{array}{c}\text { Not } \\
\text { Important }\end{array}$ & $\begin{array}{l}\text { Slightly } \\
\text { Important }\end{array}$ & $\begin{array}{l}\text { Moderately } \\
\text { Important }\end{array}$ & $\begin{array}{c}\text { Very } \\
\text { Important }\end{array}$ & $\begin{array}{l}\text { Extremely } \\
\text { Important }\end{array}$ \\
\hline 34 & $\begin{array}{l}\text { Why my Doctor suggests } \\
\text { certain tests done (e.g. } \\
\text { FBC, creatinine, X-ray, } \\
\text { Ultra sound, } \\
\text { Mammogram) }\end{array}$ & & & & & \\
\hline 35 & $\begin{array}{l}\text { What I need to do } \\
\text { before the tests }\end{array}$ & & & & & \\
\hline 36 & How tests are done & & & & & \\
\hline 37 & $\begin{array}{l}\text { How I will feel during } \\
\text { and after the tests }\end{array}$ & & & & & \\
\hline 38 & $\begin{array}{l}\text { What the results of the } \\
\text { tests mean }\end{array}$ & & & & & \\
\hline
\end{tabular}




\section{3) Treatment Modalities}

\begin{tabular}{|c|c|c|c|c|c|c|}
\hline & & $\begin{array}{c}\text { Not } \\
\text { Important }\end{array}$ & $\begin{array}{l}\text { Slightly } \\
\text { Important }\end{array}$ & $\begin{array}{l}\text { Moderately } \\
\text { Important }\end{array}$ & $\begin{array}{c}\text { Very } \\
\text { important }\end{array}$ & $\begin{array}{l}\text { Extremely } \\
\text { Important }\end{array}$ \\
\hline 39 & $\begin{array}{l}\text { The types of treatment } \\
\text { available }\end{array}$ & & & & & \\
\hline 40 & $\begin{array}{l}\text { How the treatments works } \\
\text { against the cancer }\end{array}$ & & & & & \\
\hline 41 & $\begin{array}{l}\text { Why the doctor suggests this } \\
\text { treatment plan for me }\end{array}$ & & & & & \\
\hline 42 & $\begin{array}{l}\text { The modalities which will be } \\
\text { used to deliver the treatment }\end{array}$ & & & & & \\
\hline 43 & $\begin{array}{l}\text { What I need to do to } \\
\text { prepare for treatment }\end{array}$ & & & & & \\
\hline 44 & $\begin{array}{l}\text { How long I will be } \\
\text { receiving treatment }\end{array}$ & & & & & \\
\hline 45 & $\begin{array}{l}\text { The possible side effects } \\
\text { of my treatment }\end{array}$ & & & & & \\
\hline 46 & $\begin{array}{l}\text { How I will deal with my } \\
\text { side effects }\end{array}$ & & & & & \\
\hline 47 & $\begin{array}{l}\text { What side effects I should } \\
\text { report to the Doctor/nurse }\end{array}$ & & & & & \\
\hline 48 & $\begin{array}{l}\text { If there are ways to } \\
\text { prevent side effects }\end{array}$ & & & & & \\
\hline 49 & $\begin{array}{l}\text { How I will feel after } \\
\text { my treatment }\end{array}$ & & & & & \\
\hline 50 & $\begin{array}{l}\text { If I am prone to infection } \\
\text { after my treatment }\end{array}$ & & & & & \\
\hline 51 & $\begin{array}{l}\text { Who to talk to if I have } \\
\text { questions during treatment }\end{array}$ & & & & & \\
\hline 52 & $\begin{array}{l}\text { If the treatment will } \\
\text { alter the way I look }\end{array}$ & & & & & \\
\hline 53 & $\begin{array}{l}\text { Who to talk to when I hear } \\
\text { about treatments other than } \\
\text { Surgery, chemotherapy, } \\
\text { radiotherapy or Hormonal } \\
\text { therapy }\end{array}$ & & & & & \\
\hline
\end{tabular}

\section{4) Physical Needs}

\begin{tabular}{|c|c|c|c|c|c|c|}
\hline & & $\begin{array}{c}\text { Not } \\
\text { Important }\end{array}$ & $\begin{array}{l}\text { Slightly } \\
\text { Important }\end{array}$ & $\begin{array}{l}\text { Moderately } \\
\text { Important }\end{array}$ & $\begin{array}{c}\text { Very } \\
\text { Important }\end{array}$ & $\begin{array}{l}\text { Extremely } \\
\text { Important }\end{array}$ \\
\hline 54 & $\begin{array}{l}\text { How to care for my skin } \\
\text { after the skin reactions }\end{array}$ & & & & & \\
\hline 55 & $\begin{array}{l}\text { How long my skin will take } \\
\text { to heal }\end{array}$ & & & & & \\
\hline
\end{tabular}




\section{Continued}

56 If I can wear a brassier

57 If there are special arm exercises to do

58 If can take a bath or shower

59 If I can apply anything on my body

Where I can get help if I

60 have problems feeling unattractive as I did before

61

If I can continue with my usual hobbies and sports

62 If I can continue my usual social activities

63 Where my family can go if they need help

If there are groups where I

64 can talk with other people with cancer

\section{5) Psychosocial Needs}

\begin{tabular}{llcccc}
\hline & $\begin{array}{c}\text { Not } \\
\text { Important }\end{array}$ & $\begin{array}{c}\text { Slightly } \\
\text { Important }\end{array}$ & $\begin{array}{c}\text { Moderately } \\
\text { Important }\end{array}$ & $\begin{array}{c}\text { Very } \\
\text { Important }\end{array}$ & $\begin{array}{c}\text { Extremely } \\
\text { Important }\end{array}$ \\
\hline 65 If the cancer will come back & & & \\
66 & $\begin{array}{l}\text { How to tell if the cancer } \\
\text { comes back }\end{array}$ & & \\
$67 \begin{array}{l}\text { What to do if I become } \\
\text { concerned about dying }\end{array}$ & & & \\
\hline
\end{tabular}

\section{Section E}

1) What are the barriers to accessing information by breast cancer patients at $\mathrm{CDH}$ ?

I.

II.

III

IV

V.

2) Recommendations 